\title{
Pteridophytes as primary colonisers after catastrophic events through geological time and in recent history
}

\author{
Barry A. Thomas ${ }^{1}$ (D) Christopher J. Cleal $^{2}$
}

Received: 15 September 2020 /Revised: 31 January 2021 / Accepted: 9 March 2021 / Published online: 31 July 2021

(C) The Author(s) 2021

\begin{abstract}
Pteridophytes reproduce by producing vast numbers of spores that may be dispersed over considerable distances, helping the plants colonise new areas. Being resistant to desiccation, fern spores can often survive for many years as spore banks in soil. After disturbance, such spores can germinate and subsequently colonise the area. These factors help pteridophytes to become primary colonisers on barren land, such as volcanic islands or land that has been devastated by some cataclysmic event. A further method of rapid colonisation is provided through the preservation and possible scattering of fragments of rhizomes in particular of horsetails. Similar rapid colonising by pteridophytes has been documented in the geological record following several major extinction events. These distinct, but short-lived, fern populations are recognisable by fern spikes in the microfossils. This paper brings together information on the reasons for pteridophyte success in colonising barren land, and examples taken from both the historic and geological records.
\end{abstract}

Keywords Ferns $\cdot$ Spores $\cdot$ Dispersal $\cdot$ Migration $\cdot$ Spore banks $\cdot$ Fern spikes $\cdot$ Volcanoes $\cdot$ Extinction events

\section{Introduction}

Pteridophytes include ferns, horsetails and lycopsids. Some ferns divide to form clumps, while others like the horsetails and lycopsids spread horizontally by rhizomatous growth. Pteridophytes reproduce asexually by liberating large numbers of spores which need moisture to germinate. The spores then grow into small and often inconspicuous plants called prothalli that contain the sex organs. A film of surface water is necessary to allow sperm to swim to the female sex organs called archegonia for fertilisation to occur. After fertilisation, the more conspicuous plants grow to start the process once again. By this means, pteridophytes can spread over great distance by

Barry A. Thomas

bat@aber.ac.uk

1 Institute of Biological, Environmental and Rural Sciences, University of Aberystwyth, Penglais, Aberystwyth, Ceredigion SY23 1NL, UK

2 Department of Natural Sciences, National Museum Wales, Cathays Park, Cardiff CF10 3NP, UK wind to colonise and spread. This is especially noticeable in areas where the vegetation has been recently devastated by some cataclysmic crisis. This invasion by pteridophytes can be seen to have occurred several times in the fossil record. It is now recognised that over geological time, life has suffered several major crises, the most serious being referred to as mass extinctions (e.g. Hallam 2005). At one of these mass extinctions (at the Cretaceous-Palaeogene boundary), a sharp increase in the abundance of fern spores was reported (e.g. Schultz and D'Hondt 1996; Tschudy and Tschudy 1985) that is usually referred to as a fern spike. Other examples of fern spikes have since been reported at the Triassic-Jurassic and the PermianTriassic boundaries, and are now regarded as being strong indicators of major ecological crises. In this paper, we review the evidence for post-catastrophe fern spikes in the geological record, and in the historic records of volcanic islands such as the Hawaii and the Galapagos archipelagos, and recent events brought about by volcanic activity such as Mount St. Helens, El Chichon and the islands of Surtsey and Sicily. Fern biology explains such how fern spikes occurred. A stylized sequence of extinction and subsequent recolonisation is given in Fig. 1. 


\section{Geologic records of fern spikes}

\section{The Cretaceous-Palaeogene $(\mathrm{K} / \mathrm{Pg})$ boundary}

This is widely regarded as the iconic mass extinction in the fossil record, partly because it was associated with the demise of well-known fossil animal groups such as the dinosaurs and ammonites. In many places, a clay layer found immediately above the $\mathrm{K} / \mathrm{Pg}$ boundary contains unusually high levels of the metal iridium (Fig. 2), and this is thought to represent the remains of a bolide whose impact may have caused the ecological crisis (Alvarez et al. 1980; Schulte et al. 2010) although large-scale flood-basalt eruption is now regarded as also having been at least a possible contributory factor (e.g. Ernst and Youbi 2017; Keller 2014; Richards et al. 2015). From a human perspective, it is regarded as highly significant as the destruction of the dinosaurs resulted in the subsequent diversification of our own class of animals, the Mammalia.

There is clear evidence of wildfires, global climatic cooling and extensive forest destruction at this time. Overlying the iridium layer at the $\mathrm{K} / \mathrm{Pg}$ boundary in North America, there is a layer of coal up to $0.4 \mathrm{~m}$ thick with high concentrations of monolete ferns spores - the fern spike (Pillmore et al. 1984; Tschudy et al. 1984; Tschudy and Tschudy 1985). This spike shows that the subsequent Palaeocene recovery of plants began with rapid recolonisation by a few species of ferns (Schultz and $\mathrm{D}^{\prime}$ Hondt 1996). Nichols and Johnson (2008) showed the most common fern spores to belong to the genus Cyathidites, which in the Raton Basin of Colorado and New Mexico constitutes $80 \%$ of the assemblage in the lower part of a $50-\mathrm{mm}$ thick coal overlying the boundary claystone. The peak in fern spore number is $99.5 \%$ of total pollen and spores just above the coal (Fig. 3a). Another spore Laevigatosporites is usually present in small numbers. Berry (2019) referred Cyathidites to the
Schizaeaceae, on the basis that Palaeogene Anemia foliage produced such spores, and Laevigatosporites to the Thelipteridaceae. Latitude must have affected which ferns recolonised the barren land, because at Morgan Creek in Saskatchewan, Canada, Laevigatosporites makes up $96.5 \%$ of the fern spike (Nichols et al. 1986).

For a time, it was suggested that this fern spike was an essentially local, North American, response to a biotic crisis but the discovery of contemporaneous fern spikes in New Zealand suggests that the effect of the impact was felt worldwide (Vajda et al. 2001). Two localities were discovered in New Zealand where there was a double fern spike, the first being an abundance of Laevigatosporites, followed by Gleicheniidites and Baculatispoites suggesting an initial cover of smaller ground covering ferns. The second spike was of Cyathidites and Cibotiidites, which Vajda et al. (2001) suggested was the result of large numbers of tree ferns (Fig. 3b). This view is of course contrary to that of Berry (2019) who believed that Cyathidites belonged to the Schizeaceae.

Although the K/Pg event had a major effect on the evolution of a number of animal groups, its long-term effect on vegetation seems to have been minimal (Wing 2004). A few typically Mesophytic plant groups (sensu Cleal CascalesMiñana 2014) became extinct at about this time such as the Bennettitales and Caytoniales, but these had already gone into steep decline (Anderson et al. 2007) presumably being outcompeted by the proliferating angiosperms. The overall diversification of plant families especially among angiosperms continued unabated during the Palaeogene with the appearance of many families with widespread distribution today.

\section{The Triassic-Jurassic ( $\mathrm{T} / \mathrm{J})$ boundary}

There is evidence of a significant biotic crisis at the $T / J$ boundary. Various causes have been suggested (Tanner

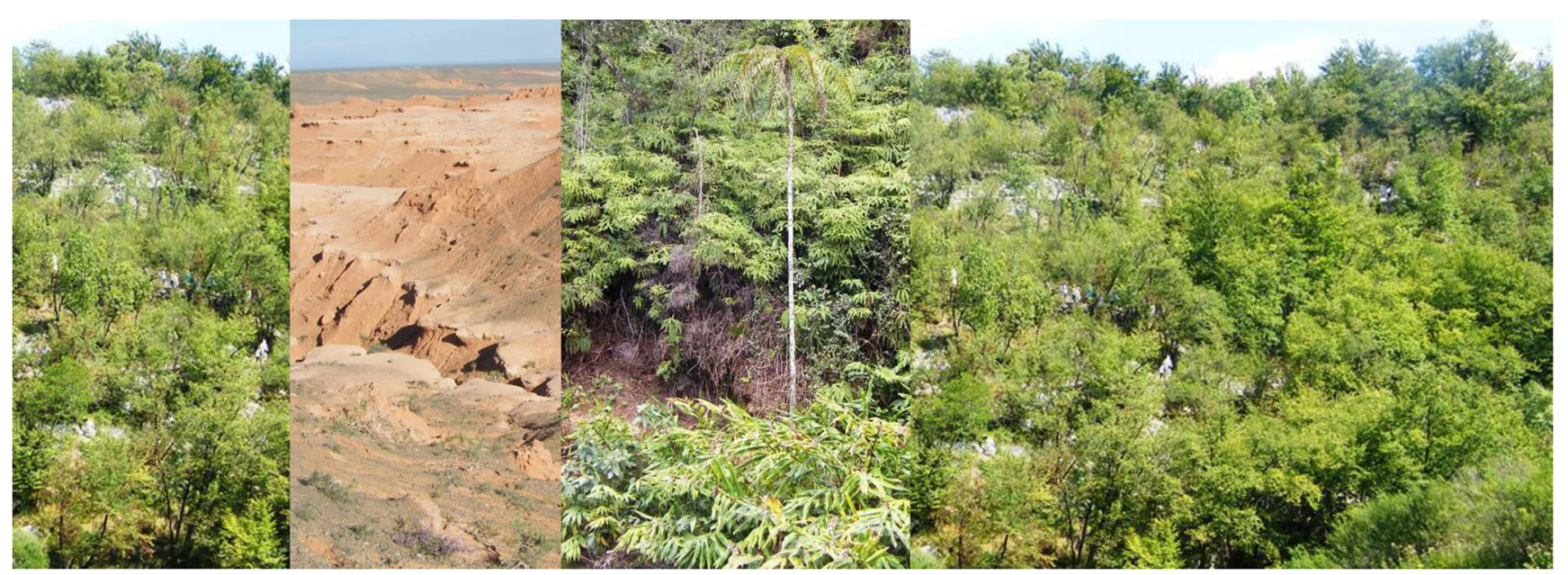

Fig. 1 A stylised representation of vegetational change brought about by a catastrophe showing forest, wasteland, fern colonisation, then back to forest 
Fig. 2 The K/Pg boundary layer exposed near Raton, NM, USA. The white layer near the hammer is the iridium-rich bed that marks the junction between the

Mesozoic and Cenozoic (from

Thomas and Cleal 1998, courtesy of R.A. Spicer)

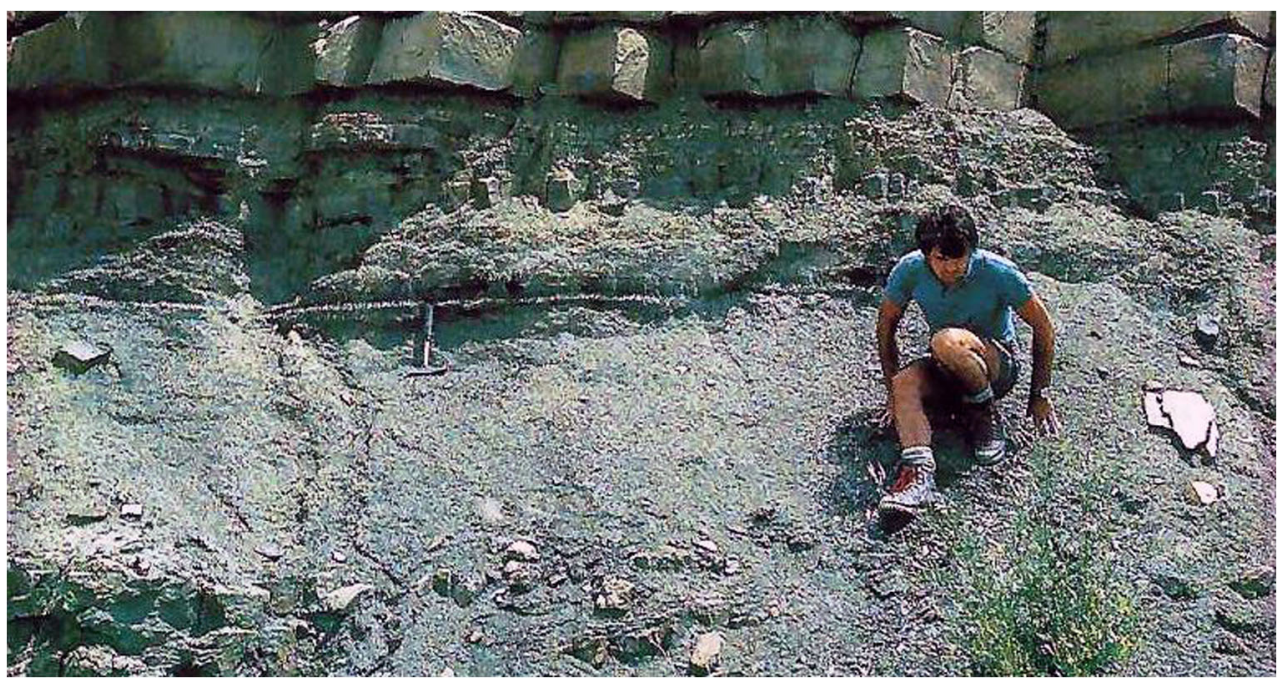

et al. 2004), but the most likely is climate change linked with the initiation of the Central Atlantic Magmatic Province and the opening of the Atlantic Ocean. It was a more prolonged ecological crisis than the $\mathrm{K} / \mathrm{Pg}$ boundary, resulting in a more gradual, step-wise biotic change

a

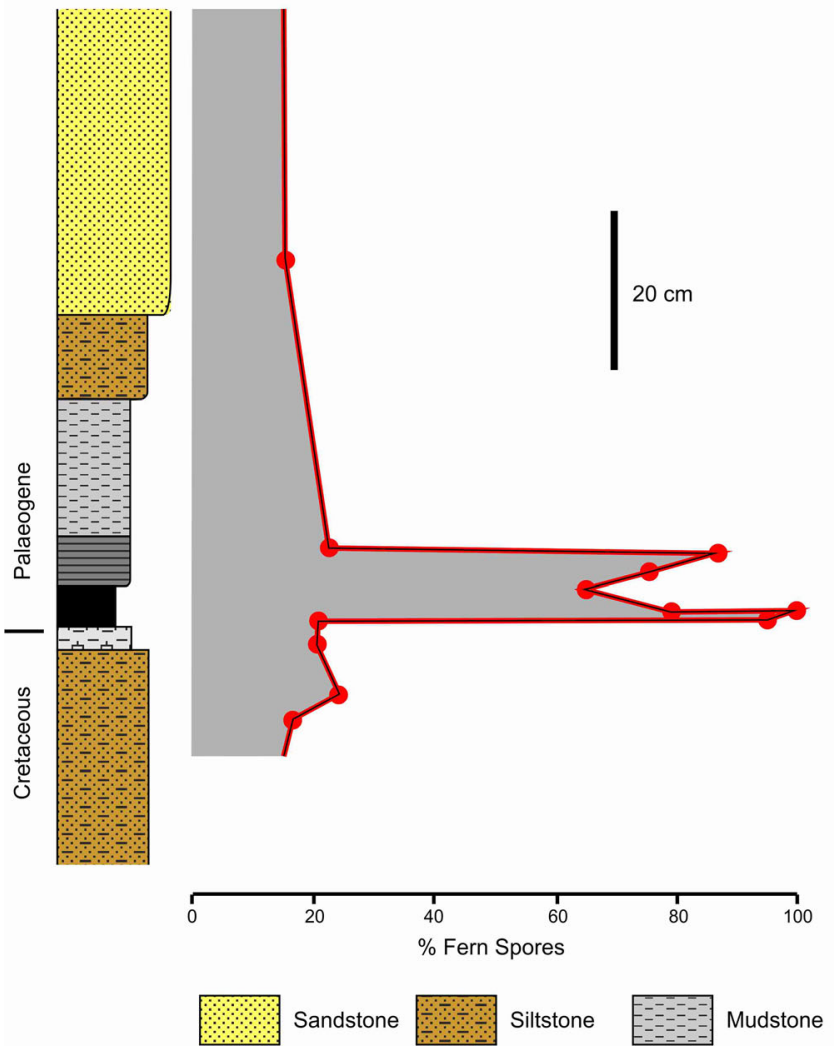

Fig. 3 a The K/Pg boundary interval at the Starkville South locality with percentages of fern spores representing a fern spike composed predominantly of Cyathidites diaphana (modified from Pillmore et al. 1999). b The boundary in New Zealand where there was a double fern spike, the occurring over c. $10 \mathrm{Ma}$ of the late Norian and Rhaetian. Overall, there was a clear reduction in faunal diversity especially in the oceans, although $60 \%$ of this was due to reduced speciation rates rather than an extinction event per se (Bambach et al. 2004).

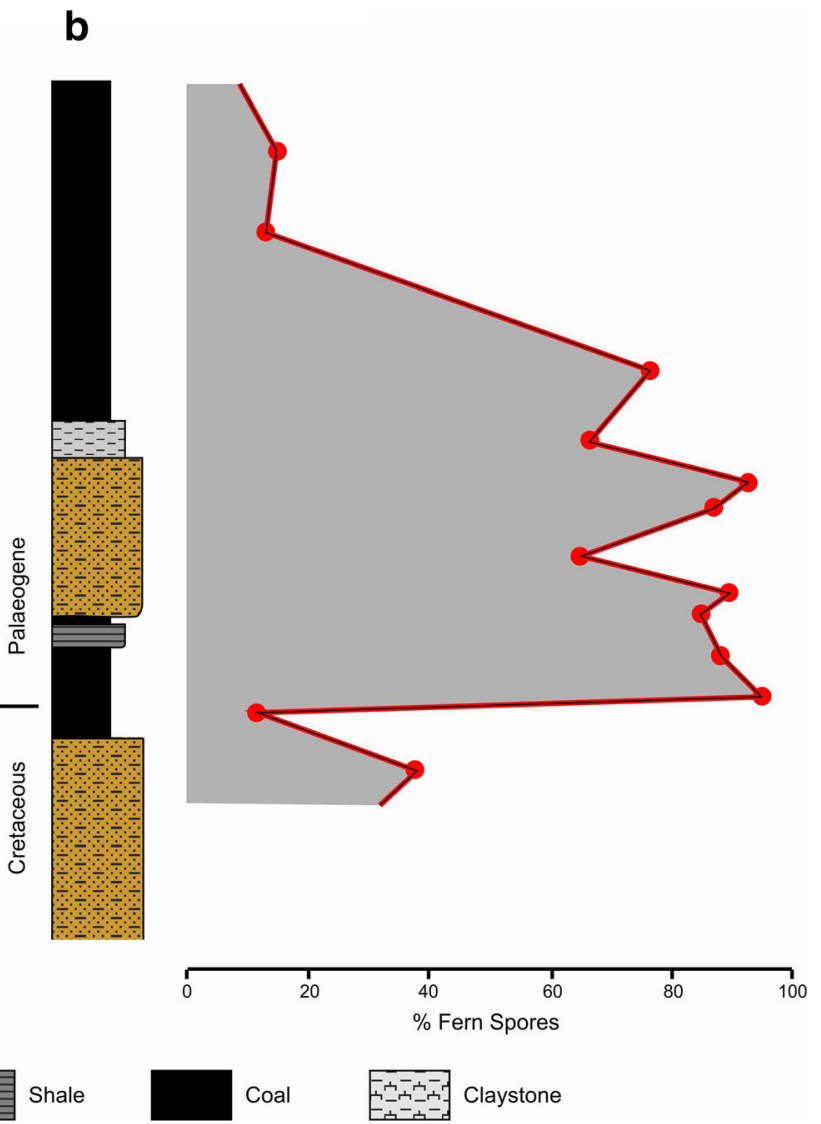

first suggesting initial cover of smaller ground covering ferns and the second spike being the result of large numbers of tree ferns (Vajda et al. 2001) 
In North America, Olsen et al. (1990) reported a fern spike at the T/J boundary (Fig. 4) similar to that seen at the K-Pg boundary, and subsequent studies elsewhere have found a proliferation of schizaeacean, osmundacean and marattialean ferns at this level (Fowell and Olsen 1993; Lindström 2016; van de Schootbrugge et al. 2007). This disruption to vegetation, probably caused by climatic warming and atmospheric pollution, was in places severe (McElwain et al. 1999, 2007; McElwain and Punyasena 2007) but probably localised (Bonis and Kürschner 2012), and had little long-term effect on plant evolution (Barbacka et al. 2017; Cascales-Miñana et al. 2018). Nevertheless, where there was substantial disruption to terrestrial habitats and it seems that ferns played a key role in the recovery of the vegetation, but this fern-dominated landscape was soon colonised by other plants resulting in a typical Jurassic plant cover and the rise of dinosaur-dominated ecosystems.

In Europe, Gravendyck et al. (2020) have demonstrated in the German Triassic that palynofloras underwent gradual changes, with three disturbance pulses leading up to the extinction interval. They documented a transition from a pre-extinction conifer forest with Cheirolepidiaceae and Voltziales, followed by successional abundances of lycopsids, leptosporangiate ferns and members of the Osmundales. Then the vegetation changed to a shrubbier and more herbaceous cycad and fern assemblage, with a diverse cryptogam flora. A conifer forest of Pinaceae, Podocarpaceae and Cheirolepidiaceae with abundant Selaginellales followed in the earliest Jurassic.

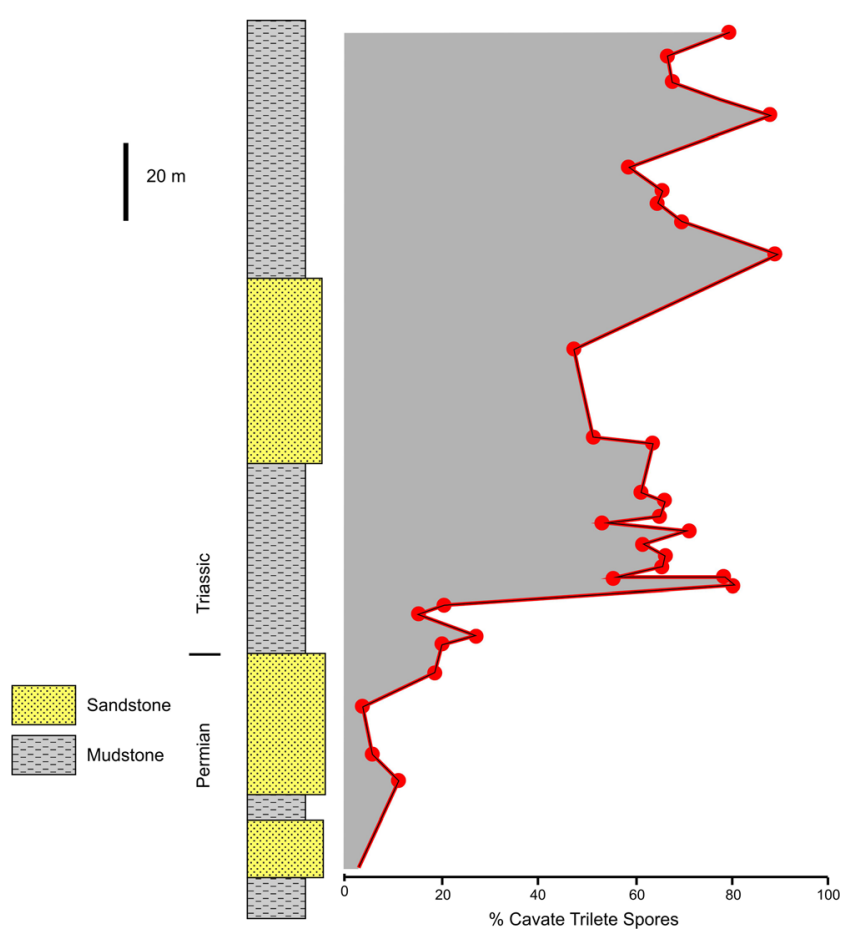

Fig. 4 The fern spike at the Permian-Triassic boundary from the Finmark bore in the Southern Barents Sea (modified from Hochuli et al. 2010)
Permian-Triassic $(\mathrm{P} / \mathrm{T})$ boundary

This has been widely regarded as the most dramatic biotic crisis in the history of Phanerozoic life, with an estimated extinction of over $90 \%$ of all species in both marine and terrestrial realms (e.g. Benton and Twitchett 2003). There have recently been some questions raised as to the severity of this crisis for vegetation (Nowak et al. 2019) but the general consensus still seems to be that the long-term consequences for plant evolution were severe (Cascales-Miñana et al. 2016; Cascales-Miñana and Cleal 2014; Rees 2002; Wing 2004).

Retallack (1995) suggested that “ ... fungal, fern, and lycopod spores show transient high abundance immediately above the Permian-Triassic boundary ...", which he compared with the fern spike at the K/Pg boundary. However, this was based on borehole data from New South Wales, Australia (Grebe 1970), where the increases in abundance were of Apiculatisporites (now Brevitriletes) of uncertain affinities, and Lundbladispora now regarded as of lycopsid, probably isoetalean affinities (Retallack 1997). Records from the Permian-earliest Triassic interval from the southern Barents Sea also show a distinct increase in spores (Fig. 5), but these are again cavate spores referred to Aratrisporites. These spores were very rare in the Griesbachian but became a significant element in the upper part of the section. Aratrisporites came from the lycopsid sporophyll Annalepsis Fliche 1910, which Looy et al. (2001) and Hochuli et al. (2010, 2016) thought came from herbaceous lycopsids of isoetalean affinity. Grauvogel-Stamm and Duringer (1983) had shown the sporophylls to be up to $45 \mathrm{~mm}$ long and $20 \mathrm{~mm}$ wide, coming from cones with a diameter of up to $140 \mathrm{~mm}$. They believed the sporophylls to be similar to those of the Carboniferous

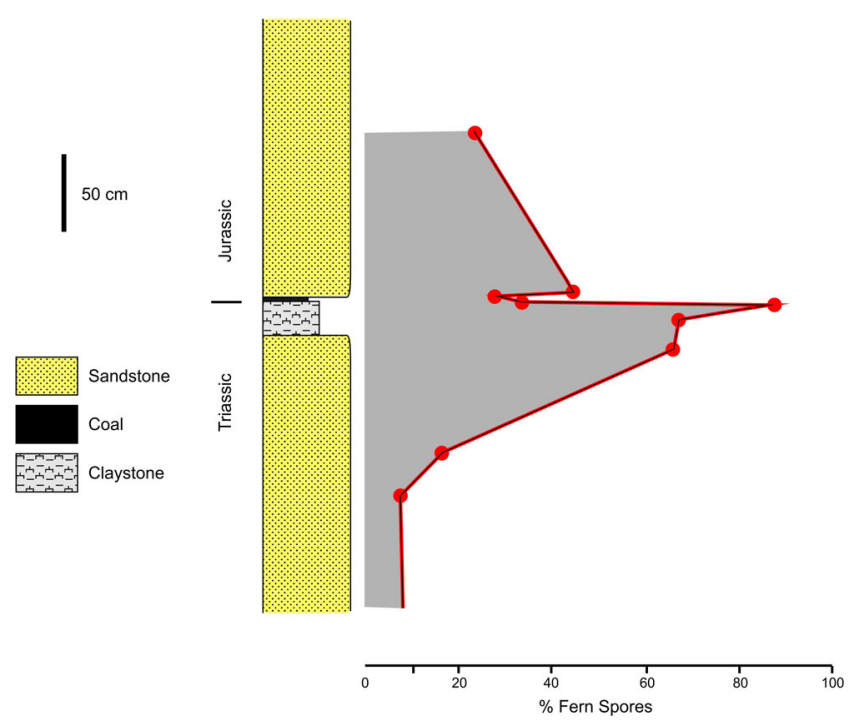

Fig. 5 The fern spike from the Jacksonwald syncline section of the Newark Basin at the Triassic-Jurassic boundary. Percent spore data are averaged from three sections (Modified from Olsen et al. 2002) 
Lepidodendraceae suggesting Annalepsis was perhaps one of their descendants. Such plants may have taken a number of years to grow from spores and reach maturity Nevertheless, in terms of geological time, this was insignificant. Aratrisporites and other spores attributable to the lycopsids, comprising Densoisporites, Kraeuselisporites and Lundbladispora, show average abundances of 10-20\% of the total spore/pollen count in the Griesbachian but up to $90 \%$ of total spore/pollen in the uppermost part of the section.

There is also evidence of vegetation change in Antarctica at the P/T boundary, although Cantrill and Poole (2012) stated that this can only be inferred from several key floras. It was associated with the general demise of the glossopterid flora. Even the best documented palynofloras show a gap at the transition point between the Permian and the Triassic, but Lindström and McLoughlin (2007) show the dominance of spore-producing plants in the earliest Triassic vegetation suggesting that it was more open than that of the Permian. Ferns were common, indicated by an increase of the spores Lopholotriletes and Osmundacidites, both of which had survived from the Permian vegetation and there were also many lycopsids (McLoughlin, Lindström and Drinnan 1997). Unfortunately, the only records of macrofossil ferns date from the early Middle Triassic with species belonging to the Gleicheniaceae, Osmundaceae, Marattiaceae, Matoniaceae, Dipteridaceae and some others not referred to families (Cantrill and Poole 2012).

Fielding et al. (2019) in their study of the Sydney Basin in Australia came to the conclusion that the terrestrial extinction interval, which was represented by a collapse of the Glossopteris flora, the cessation of coal-forming conditions, together with enhanced levels of phytoplankton, occurred $\sim 370$ thousand years before the onset of the marine extinction interval. They did, however, report a sudden increase in the filicalean fern Brevisporites at this level that could be equated to a fern spike. This terrestrial extinction in the Sydney Basin was calculated to be approximately concurrent with the onset of the primary extrusion phase of the Siberian Traps volcanism. They suggested that, despite the different timings of the terrestrial and marine biotic collapses, the likely trigger in both realms was the result of the Siberian volcanism.

One reason for the late recovery of ferns in the Triassic is because many of the Permian taxa belonged to the Marattiaceae which were large and eusporangiate with large thick-walled sporangia containing large numbers of spores. They had no active dispersal mechanism in their sporangia like the leptosporangiate ferns which hindered the widespread dispersal of their spores. This would have prevented them from making a rapid recovery after an extinction event. The other group of ferns that appeared in late Permian times was the Osmundaceae, which has the most extensive record of any family of ferns (Bomfleur et al. 2015). These Permian members of the Osmundaceae were large with trunks consisting of stems surrounded by a mantle of leaf bases and roots so they were not the sort of ferns that could make a rapid come back after an extinction event. Living members of the Osmundaceae have green spores that have a short viability of about 2 months (Hoshizaki Moran 2001). If this were the case with the Permian species, it would be another reason why the ferns could not make a rapid comeback to form a fern spike. It was not until after the $\mathrm{P} / \mathrm{T}$ extinction event that many modern groups of smaller ferns evolved with more resistant spores and sometimes rhizomes that allowed them to survive and make rapid recoveries to produce fern spikes as at the $\mathrm{K} / \mathrm{Pg}$ and $\mathrm{T} / \mathrm{J}$ boundary events.

\section{Ferns and modern-day disturbed habitats}

In modern disturbed ecosystems ferns and, less often, lycopsids and horsetails play important roles in restoration of the ecosystems because of their ability to grow in nutrient-poor substrates or in acidic water-logged conditions, both of which are associated with volcanic activity (Page 2004). After the clearance of tree cover, such opportunistic pteridophytes spread rapidly and can form extensive cover that delays the introduction of other plants (Walker 2010). Eventually, as other vascular plants start to colonise the area, the pteridophyte cover is curtailed and only survives in smaller areas in the succeeding forests.

\section{Volcanic islands}

Long-distance wind transportation is responsible for the dispersal and migration to isolated volcanic islands. Most species of ferns have spores that can remain viable in air dried conditions for several months (Tryon 1970, 1995; Barrington 1993; Smith 1993). However, as pointed out by Holtum (1938), dispersal is not limited by wind dispersal but by the ability of the spores to survive. This is especially true for thin-walled and green spores of such as the belonging to the Osmundaceae, some Hymenophyllaceae and some of the grammitid and onocleoid ferns in the Polypodiaceae (Tryon 1970). They have high water content and rapid respiration, factors which result in the spores remaining viable for only a short time (Rush 1984). They can last for a month or so which means that they must have been transported rapidly by strong winds in order for them to become widely distributed on several continents and on the Azores and Cape Verde Islands (Tryon 1970).

Sicily: The large active volcano on Sicily is Etna. Bracken (Pteridium) has been described as an obvious coloniser on the more stable slopes where the lava flows dating from 2008 are a mixture of medium and large clinker. The bracken colonising this area has been shown to be severely limited by 
the clinker restricting its rhizome growth (Thomas 2016). The fronds are not separated as they are in open habitats but in discrete clusters of 20 or more shoots in very close proximity (Fig. 6a). Other areas are covered by fine cinders that came from a violent explosion, which sent tons of lava into the air that cooled and solidified into small and lightweight pieces full of air holes. Mature trees of birch and pine colonised much of this area, but bracken is still there in large numbers, again in clusters presumably being limited in growth by underlying lava (Fig. 6b). What is not clear is whether the bracken growth has resulted from surviving pieces of rhizome or re-established through spore dispersal.

Hawaii: This comprises a linear archipelago of eight major islands, several atolls, numerous smaller islets and seamounts, extending over $2400 \mathrm{~km}$ in the North Pacific Ocean. They are $3200 \mathrm{~km}$ from the nearest land mass, and vegetation colonisation may have started about 23 million years ago. Geiger et al. (2007) suggest that some species are believed to have colonised the islands more than once. Of the 161 species of pteridophytes on the islands, $71 \%$ are endemic (Palmer 2003) although there is much variation within them. This variation may be either because of changes in island geography over time that brought taxa together which produced fertile hybrid continuums or because not enough time has elapsed for them to separate into new species.

Studying volcanic surfaces of known ages has shown that there has to be a sequence of ferns where each was adapted to a part of the succession of habitats. The first to invade were the scrambling fern Dicranopteris linearis, Nephrolepis exalta and the clubmoss Lycopodiella cernua. After about 300 years, they were replaced by the tree fern Cibotium glaucum. It is only after several thousand years of succession that Athyrium sandwichianum became important (Clarkson 1997; Kitayama et al. 1985). The tree ferns can form dense populations that are sometimes self-perpetuating (Fig. 7). Some of these thickets have persisted for over 2000 years by regenerating through spores and rooting trunk buds (Derroire et al. 2007). The problem facing the indigenous ferns' flora is the increasing numbers of cultivated ferns that are escaping into the wild with some becoming widespread and displacing native ferns, while others are hybridising with them (Robinson et al. 2010).

Galapagos Islands: These islands, which are about $1000 \mathrm{~km}$ west of South America, played an important role in the study of evolutionary biology. Although there are no records of plant colonisation of the islands, many pteridophyte spores were transported there by wind or possibly on the feet of birds. Anderson (1958) made a preliminary study of the number of fern and lycopsid species on the islands and suggested they were directly related to the size of the islands. This would be in line with the theory of island biogeography as outlined by MacArthur and Wilson (1967). Tryon (1970) made the point that the Galapagos Islands, with a total area of 3000 square miles, has a fern flora is of about 70 species. Reunion in contrast is 970 square miles in size, with a fern flora of 159 species (Derroire et al. 2007). A larger island may provide a better target for spores, but differences in wind patterns, local environment and distance from the source all contribute to these differences.
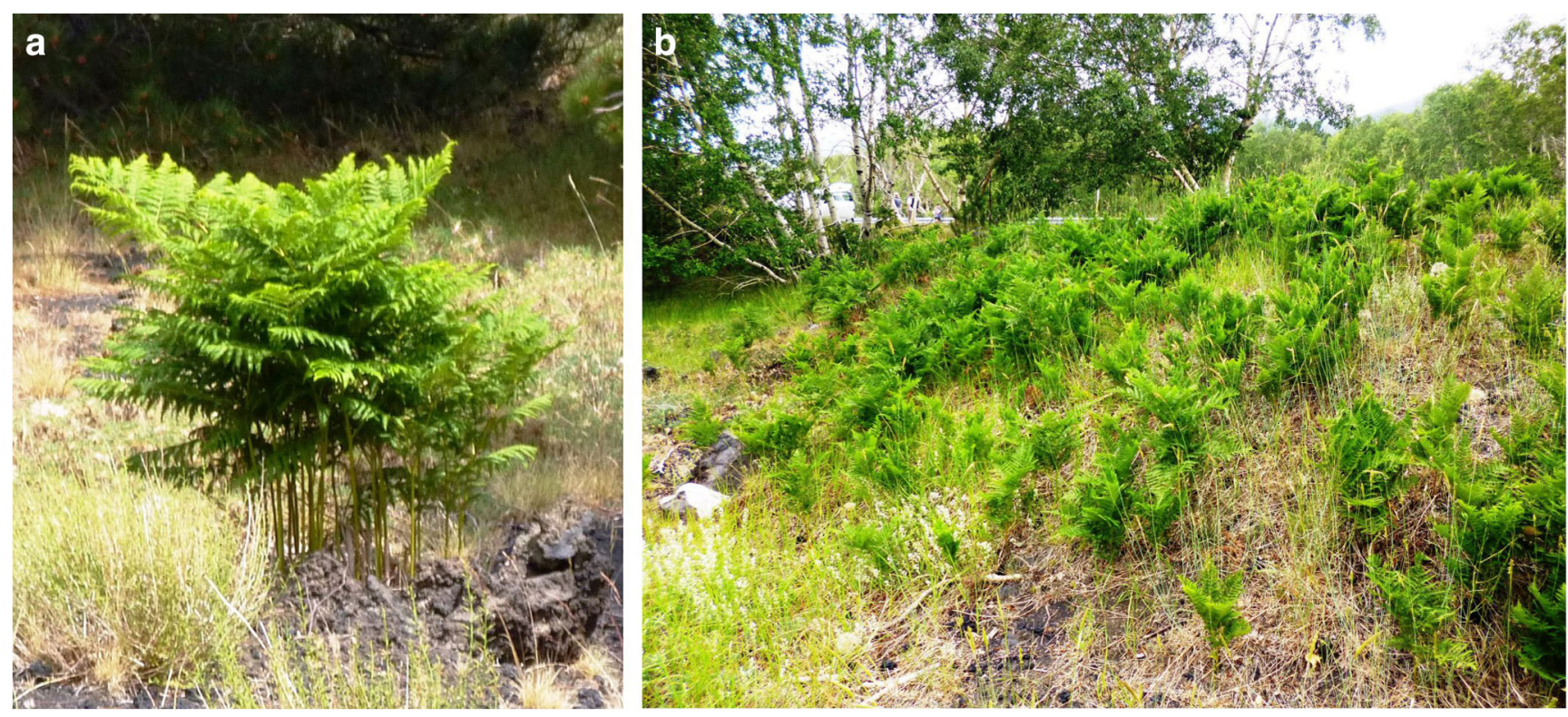

Fig. 6 a Bracken clusters of approximately 20 plants on recent lava field on the slopes of Etna on Sicily. b Bracken growing under fine ash under stands of birch and pine (From Thomas 2016) 


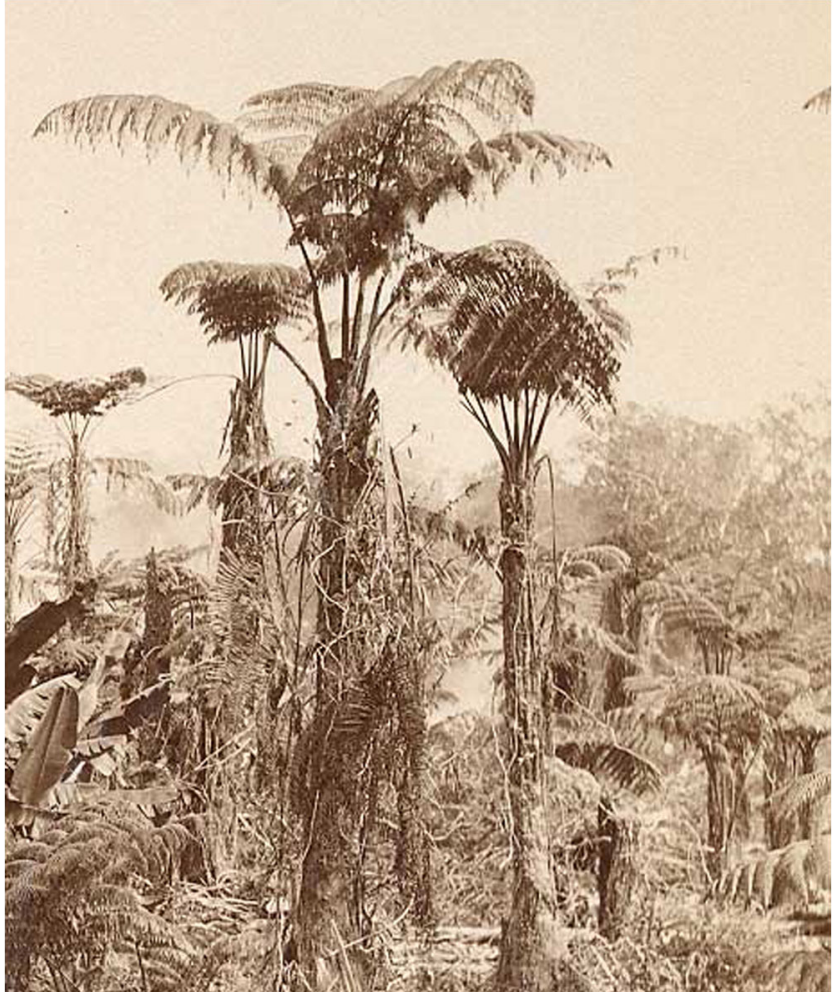

Fig. 7 An undisturbed stand of tree ferns in Hawaii in the nineteenth century. The taller ferns are one of four species of Cibotium endemic to Hawaii (from Cleal and Thomas 2019)

Krakatoa (Krakau): This island in the Indonesian Arc between Sumatra and Java violently erupted in 1883, completely destroying the natural vegetation (Dörries 2003; Simkin Fiske 1883). Although the island was uninhabited, the tsunami that followed killed about 36,000 people. The re-vegetation of the island started soon afterwards, and studies revealed a shortlived dominance by ferns whose spores had been blown there (Tschudy et al. 1984). Three years after the eruption, there were 10 species of fern, and the next year Ophioglossum moluccanum and Lycopodium cernuum arrived on the island. By 1919, there were 49 species of pteridophytes rising to 63 species by 1929 (Whittaker et al. 1989).

Surtsey: The Vestmannaeyjar archipelago, which consists of 18 small islands off the south coast of Iceland, forms a young volcanic system with the oldest rock formations dating from 40,000 years BP. Surtsey is the most southern and youngest of the islands being formed by a volcanic eruption that lasted from November 1963 to June 1967. The island eventually reached an area of $2.7 \mathrm{~km}^{2}$ and a height of $173 \mathrm{~m}$, although subsequent erosion has reduced the island to about half its original size (Fig. 8a). The succession of plants and animals has been monitored since volcanic activity ceased, and in 1990 , permanent monitoring plots were established
(Magnússon et al. 2014). Monitoring has revealed that, during the first few years, shore plants, dispersed by the sea, were the main pioneers on the island with the first plant to arrive on the island being the sea rocket (Cakile maritima). The fern Cystopteris fragilis (Fig. 8b) was also an early coloniser resulting from its spores being carried by the wind. One of the most recent colonisers is the fern Moonwort (Botrychium lunaria), which was first found on the island in 2011 (Fig. 8c). Of the 69 plant species recorded on the island since 1965 , about $75 \%$ have presumably been dispersed by birds, $15 \%$ by wind and $10 \%$ by the sea.

Mainland volcanoes

El Chichón: In March 1982, this southern Mexican volcano erupted with three pyroclastic surges and flows that destroyed $154 \mathrm{~km}^{2}$ of tropical rainforest and agricultural land. Volcanic debris was several metres thick, but the local high rainfall of over $2000 \mathrm{~mm}$ per annum formed numerous erosion gulleys that in some cases were worn down to the original soil level. Within 2 years, in the regions where devastation was most intense, the fern Pityrogramma calomelanos was the primary coloniser (Fig. 9a). In the deep gullies, regeneration was from rhizomes in the pre-eruption soil that had survived both thermal shock and high concentrations of sulphur and acid rain. These plants grew quickly and produced fertile fronds (Fig. 9b). Numerous young plants, typically 50 $70 \mathrm{~mm}$ tall, were soon growing on the stable pumicestrewn slopes in fine tephra between the blocks of pumice at densities of about 40 per $\mathrm{m}^{2}$. Clearly, vast numbers of spores from the surviving plants had been wind dispersed, and the prothalli were able to grow and form sporophytes with virtually no competition from other plants (Spicer et al. 1985).

Mount St. Helens: On May 18, 1980, this volcano in Washington State, USA exploded violently after 2 months of intense earthquake activity and intermittent weak eruptions. During the eruption, a $480-\mathrm{km}$-an-hour lateral blast of hot air and debris destroyed $370 \mathrm{~km}^{2}$ of forests, lakes, meadows and streams and formed a cloud of ash at $24 \mathrm{~km}$ in $15 \mathrm{~min}$ (Fig. 10a). Some survivors such as willow, vine maple and black cottonwood were able to re-sprout from roots that had been protected in the underlying moist soil and a number of snowprotected Pacific silver fir and mountain hemlock trees also survived the blast (Del Moral and Wood 1988; Ingrouille and Eddie 2006). However, there were great expanses of barren land (Fig. 10b), and among the first plants to recolonise, these were large numbers of horsetails (Equisetum) growing from pieces of rhizome that had survived the blast (Fig. 11). Ferns did not take part in the early recolonisation because the soil surface was too dry. 

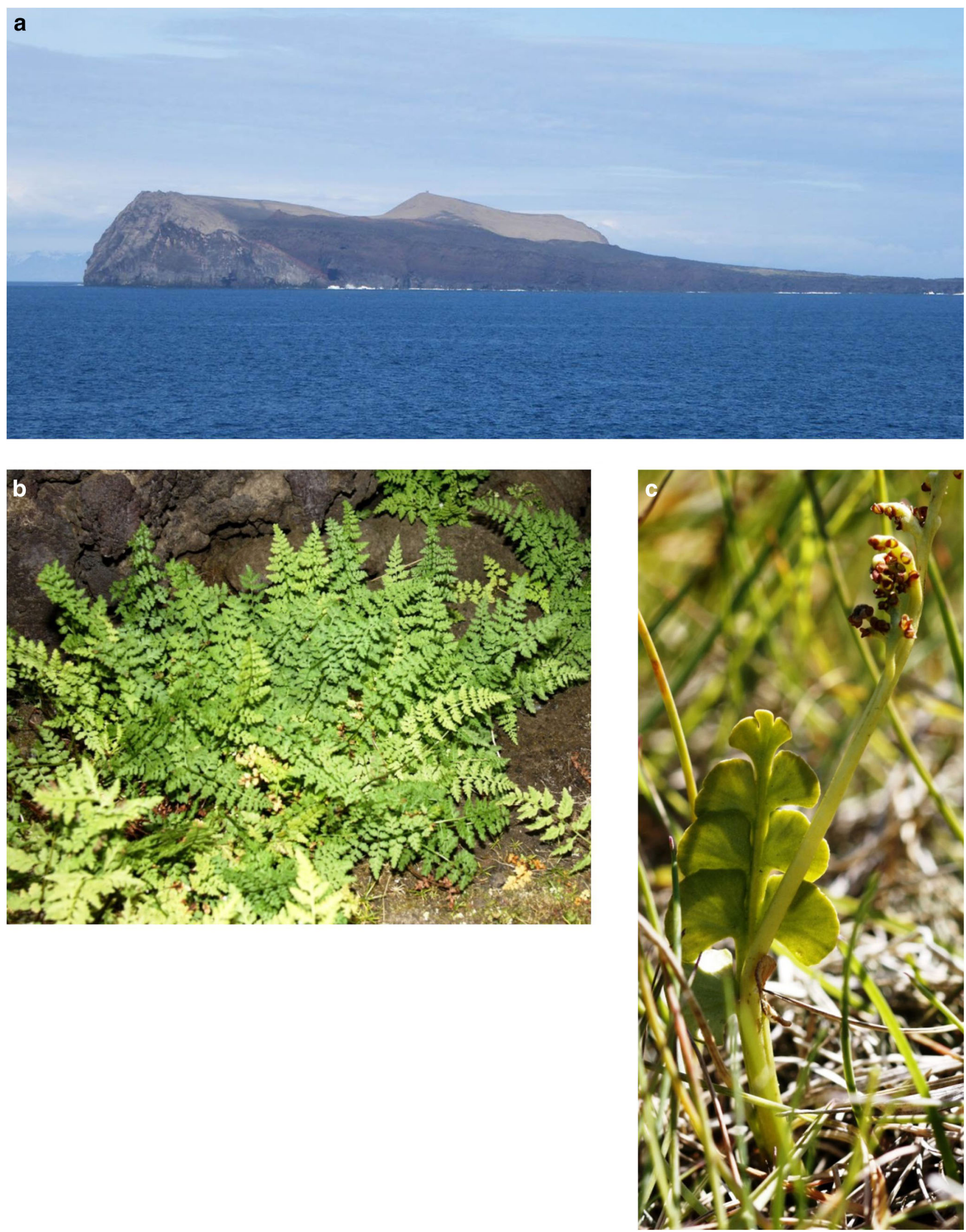

Fig. 8 a The island of Surtsey from the west showing the vegetation cover (photograph B.A. Thomas); b Cystosporites fragilis and $\mathbf{c}$ Botrychium lunaria (photographs by Borgbór Magneson with permission) 

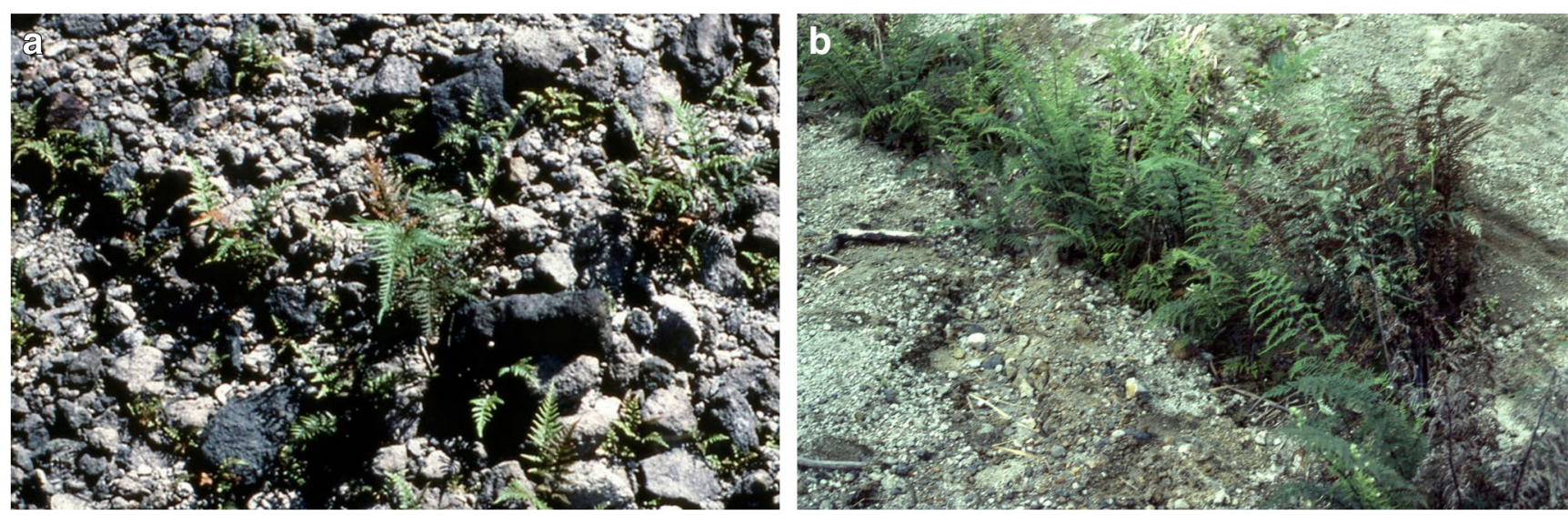

Fig. 9 Pityrogramma calomelanos growing on El Chichón in southern Mexico. a Mature plants thriving in a gulley. b Young plants growing on the fine tephra (photographs by RA Spicer with permission)

\section{Discussion}

The examples outlined above show that there have been many occasions when catastrophic events had destroyed the existing vegetation but this was followed by primary recolonisation by pteridophytes. Indeed, if we look further back in time to the Carboniferous, there is evidence that arborescent lycopsids were the primary colonisers in the Euramerican coal swamps after the vegetation had been destroyed by cyclone-like storms responsible for dramatic influxes of sediment into the depositional basin (Thomas and Cleal 2015).

There appears to be something intrinsic to the biology of at least some ferns and lycopsids that make them adapted to colonising disturbed habitats. Ferns produce enormous
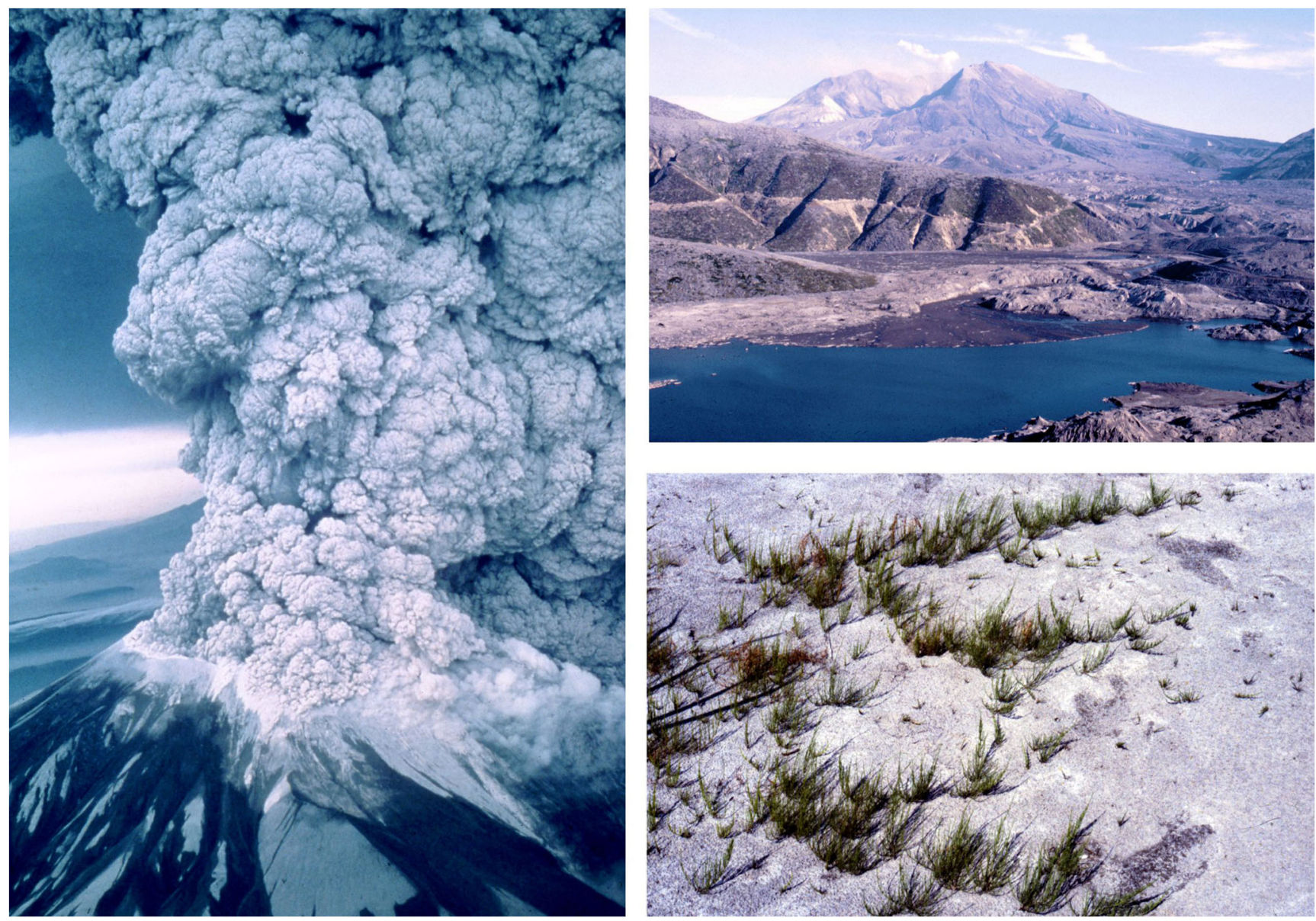

Fig. 10 Mount St. Helens showing the explosion and the following devastation (photographs by RA Spicer with permission). 


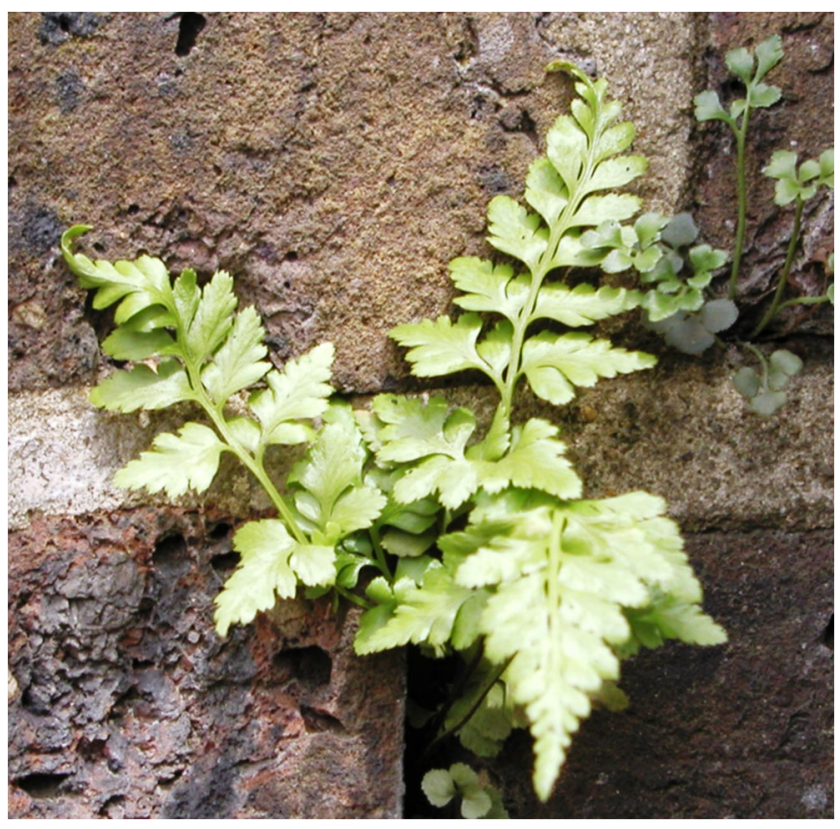

Fig. 11 Asplenium adiantum-nigrum colomising a wall in south London. (Photograph by P. Acock with permission)

numbers of spores; for example, one frond of Dryopteris carthusiana is able to shed 7,305,216 spores (Moran 2004). Ferns often colonise habitats that have been disturbed by tectonic activity, wind, water, fire or humans. Although many spores do not travel very far from the parent plant, colonisation can be over a several kilometres, as shown by Edington (2007) in the spread of Asplenium adiantum-nigrum and Asplenium trichomanes across inner London. Both ferns are calcicoles that grow in the mortar of brick walls, and their spread has been contemporaneous with a decline in sulphur dioxide. The mean distance between a newly established sporophyte to the nearest potential parent plant was calculated to be $0.75 \mathrm{~km}$. Because there was still no uniformity in distribution and the density of new sites was greatest near the first recorded sites, Edington suggested that colonisation was continuing. Dispersal can sometimes take spores far away from the parent plant with some being transported for long distances via air currents such as trade winds or storm systems or even in high-altitude jet streams for thousands of kilometres (Perrie and Brownsey 2007).

Spores have protective outer layers, which in mature spores are often highly ornamented and resistant to desiccation. This allows them to survive if they are washed into the soil or loose sediments either close to the parent plant or far away (Gams 1938). Here, they can remain viable for many years in what are known as "spore banks" (Dyer and Lindsay 1992, 1996; Hamilton 1988; Lindsay 1995; Milberg 1991; Milberg and Anderson 1994; Schneller 1988) until disturbance brings them back to the surface. If conditions are right, the spores will then germinate and grow into sexually active prothalli, which after fertilisation produce sporophytes. Rydgren and Hestmark (1996) reported that spores of Athyrium filix-femina were the most frequent type of spores in soil banks within a boreal oldgrowth Spruce forest in Canada. Bremer (2010) has shown how ten fern species and three species of horsetail became established in woodland gaps following the cutting of trees. Asplenium filix-femina was the most successful and formed dense stands in some of the gaps. Three fern species (Thelypteris palustris, Dryopteris cristata and Matteuccia struthiopteris) and Equisetum telmateia had not been previously recorded from the woodland. There was no correlation between the burst of colonisation and the surrounding sparse population of ferns. Bremer (2010) suggests that the colonisation of the less common species was a combination of recovery from an extensive number of spores preserved in the soil spore bank followed by further dispersal from established plants.

Regeneration of Equisetum is rather different. If it were present at the time of destruction, its deep rhizomes might well have survived thereby permitting subsequent growth of aerial photosynthetic shoots. These plants are even tolerant of soil anoxia, high metals and salinity (Husby 2013). Disruption of the soil layer itself would probably break up the spreading rhizome into fragments, which would increase the potential for its future growth and recolonisation. However, even though they are homosporous, horsetails are not efficient at dispersing their spores over long distances, so they are absent from Australia, New Zealand and many oceanic islands. Zajączkowska et al. (2017) have suggested that the stems of Equisetum are very stable with any disturbance resulting in vibration of the top where the cones are located. This stability results in spores only being liberated during prolonged wind.

\section{Conclusions}

The dispersal strategies of pteridophytes and especially ferns have made them ideally suited to invading disturbed habitats as primary colonisers especially following major ecological crises such as mass extinctions and volcanic activity. The presence of fern spikes in the geological record from the Triassic onwards illustrates that more modern, leptosporangiate ferns with their smaller sporangia and advanced dehiscence mechanisms are more efficient colonisers than the eusporangiate ferns. If conditions were too dry on the surface for fern spores to germinate, regrowth from the deep rhizomes of horsetails might then result in their domination in the initial phase of regeneration.

However, this effect is mainly seen in the more recent, Cenophytic vegetation; evidence of fern spikes in the Mesozoic is weaker and, in the Palaeozoic, virtually non-existent. This presumably reflects significant differences in the reproduction and dispersal strategies between the Cenophytic ferns and those of the Mesophytic and Palaeophytic floras. 
Reproduction and dispersal are obviously active processes that cannot be observed directly in the fossil record, but morphological and/or structural adaptations to facilitate those processes may be fossilised. Further comparative analyses of features such as sporangium structure and spore ultrastructure in fossil ferns may, therefore, throw important new light on why fern spikes occur in comparatively modern vegetation but less so in the past.

Acknowledgements We thank Patrick Acock, Borgbór Magneson and Robert Spicer for providing photographs and Dr WM Kürschner and an anonymous person for their helpful review comments This is a contribution to National Museum Wales Project NS25: Plant diversity through 450 million years of Earth history.

\section{Declarations}

Conflict of interest The authors declare that they have no conflicts of interest.

Open Access This article is licensed under a Creative Commons Attribution 4.0 International License, which permits use, sharing, adaptation, distribution and reproduction in any medium or format, as long as you give appropriate credit to the original author(s) and the source, provide a link to the Creative Commons licence, and indicate if changes were made. The images or other third party material in this article are included in the article's Creative Commons licence, unless indicated otherwise in a credit line to the material. If material is not included in the article's Creative Commons licence and your intended use is not permitted by statutory regulation or exceeds the permitted use, you will need to obtain permission directly from the copyright holder. To view a copy of this licence, visit http://creativecommons.org/licenses/by/4.0/.

\section{References}

Alvarez, L. W., Alvarez, W., Asaro, F., \& Michel, H. V. (1980). Extraterrestrial cause for the Cretaceous-Tertiary extinction. Science, 208, 1095-1108.

Anderson, H. (1958). Nul hypothesis in the Galapagos Islands. In U. J. During, M. J. A. Werger, J. H. Willems (Eds.), Diversity and patterns in plant communities (pp. 37-46). The Hague: Academic Press.

Anderson, J. M., Anderson, H. M., \& Cleal, C. J. (2007). Brief history of the gymnosperms: classification, biodiversity, phytogeography and ecology. Pretoria: National Biodiversity Institute.

Bambach, R. K., Knoll, A. H., \& Wang, S. C. (2004). Origination, extinction, and mass depletions of marine diversity. Paleobiology, 30, 522-542.

Barbacka, M., Pacyna, G., Kocsis, Á.T., Jarzynka,, A., Ziaja, J., \& Bodor, E. (2017) Changes in terrestrial floras at the Triassic-Jurassic Boundary in Europe. Palaeogeography, Palaeoclimatology, Palaeoecology, 480, 80-93.

Barrington, D. S. (1993). Ecology and historical factors in fern biogeography. Journal of Biogeography, 20, 275-280.

Benton, M. J., \& Twitchett, R. J. (2003). How to kill (almost) all life: the end-Permian extinction event. Trends in Ecology Evolution, 18, $358-365$.
Berry, K. (2019). Fern spore viability considered in relation to the duration of the Cretaceous-Paleogene (K-Pg) impact winter. A contribution to the discussion. Acta Palaeobotanica, 59, 19-25.

Bomfleur, B., Grimm, G. W., \& McLoughlin, S. M. (2015). Osmunda pulchella sp. nov. from the Jurassic of Sweden - reconciling molecular and fossil evidence in the phylogeny of modern royal ferns (Osmundaceae). Evolutionary Biology, 15, 126-151.

Bonis, N. R., \& Kürschner, W. M. (2012). Vegetation history, diversity patterns, and climate change across the Triassic/Jurassic boundary. Paleobiology, 38, 240-264.

Bremer, P. (2010). The colonisation of woodland gaps by ferns and horsetails. Fern Gazette, 18, 308-318.

Cantrill, D. J., \& Poole, I. (2012). The vegetation of Antarctica through geological time. Cambridge: University Press.

Cascales-Miñana, B., \& Cleal, C. J. (2014). The plant fossil record reflects just two great extinction events. Terra Nova, 26, 195-200.

Cascales-Miñana, B., Diez, J. B., Gerrienne, P., \& Cleal, C. J. (2016). A palaeobotanical perspective on the great end-Permian biotic crisis. Historical Biology, 28, 1066-1074.

Cascales-Miñana, B., Servais, T., Cleal, C. J., Gerrienne, P., \& Anderson, J. (2018). Plants - the great survivors! Geology Today, 34, 224-229.

Clarkson, B. C. (1997). Vegetational succession on five recent montane lava flows, Mauna Loa, Hawaii. New Zealand Journal of Ecology, $22,1-9$.

Cleal, C. J., \& Cascales-Miñana, B. (2014). Composition and dynamics of the great Phanerozoic Evolutionary Floras. Lethaia, 47, 469-484.

Cleal, C. J., \& Thomas, B. A. (2019). Introduction to Plant Fossils, 2nd edn. Cambridge University Press, p 246.

Del Moral, R., \& Wood, D. M. (1988). Dynamics of herbaceous vegetation recovery on Mount St. Helens, Washington, USA, after a volcanic eruption. Biological Reviews, 77, 279-310.

Derroire, G., Schmitt, L., Rivière, J.-N., \& Tassin, J. (2007). The essential role of tree-fern trunks in the regeneration of Weinmannia tinctora in the rain forest in Reunion, Mascarette Archipelago. Journal of Tropical Ecology, 23, 487-492.

Dörries, M. (2003). Global science: the eruption of Krakatau. Endeavour, $27,113-116$

Dyer, A. F., \& Lindsay, S. (1992). Soil spore banks of temperate ferns. American Fern Journal, 82, 69-123.

Dyer, A. F., \& Lindsay, S. (1996). Soil spore banks - A new resource for conservation. In J. M. Camus, M. Gibby, R. J. Johns (Eds.), Pteridology in perspective (pp. 151-160). Kew: Royal Botanic Gardens.

Edginton, J. A. (2007). Dynamics of long-distant dispersal: the spread of Asplenium adiantum-nigrum and Asplenium trichomanes (Aspleniaceae: Pteridophyta) on London walls. Fern Gazette, 18, 31-38.

Ernst, R. E., \& Youbi, N. (2017). How large igneous provinces affect global climate, sometimes cause mass extinctions, and represent natural markers in the geological record. Palaeogeography, Palaeoclimatology, Palaeoecology, 478, 30-52.

Fielding, C. R., Frank, T. D., McLoughlin, S., Vajda, V., Mays, C., Tevyaw, A. P., Winguth, A., Winguth, C., Nicoll, R. S., Bocking, M., \& Crowley, J. L. (2019). Age and pattern of the southern highlatitude continental end-Permian extinction constrained by multiproxy analysis. Nature Communications, 10(1), 385. https:// doi.org/10.1038/s41467-018-07934-z.

Fowell, S. J., \& Olsen, P. E. (1993). Time calibration of Triassic/Jurassic microfloral turnover, eastern North America. Tectonophysics, 222, 361-369.

Gams, H. (1938) Ökologie der extratropischen Pteridophyten. In F. Verdoon. (Ed.). Manual of Pteridology (pp. 417-418). The Hague: Nijhoff. 
Geiger, J. M. O., Ranker, T. A., Neale, J. M. R., \& Klimas, S. T. (2007). Molecular biogeography and origins of the Hawaiin fern flora. Brittonia, 59, 142-155.

Grauvogel-Stamm, L., \& Duringer, P. (1983). Annalepis zeilleri Fliche 1910 emend. un organe reproducteur de Lycophyte de la Lettenkohle de l'Est de la France. Morphologie, spores in situ et paléoécologie. Geologische Rundschau, 72, 23-51.

Gravendyck, J., Schobben, M., Bachelier, J., \& Kürschner, W. M. (2020). Macroecological patterns of the terrestrial vegetation history during the end-Triassic biotic crisis in the central European Basin: A palynological study of the Bonenburg section (NW-Germany) and its supra-regional implications. Global and Planetary Change, 194, 103286.

Grebe, H. (1970). Permian plant microfossils from the Newcastle Coal Measures/Narrabeen Group boundary, Lake Munmorah, New South Wales. Records. Geological Survey of New South Wales, 12(2), $125-136$.

Hallam, A. (2005). Catastrophes and lesser calamities: the causes of mass extinctions. Oxford: University Press.

Hamilton, R. G. (1988). The significance of spore banks in natural populations of Athyrium pycnocarpon and A. thelipteroides. American Fern Journal, 68, 98-104.

Hochuli, P. A., Hermann, E., Vigran, J. O., Bucher, H., \& Weissert, H. (2010). Rapid demise and recovery of plant ecosystems across the end-Permian extinction event. Global and Planetary Change, 74, 144-155.

Hochuli, P. A., Sanson-Barrera, A., Schneebeli-Hermann, E., \& Bucher, H. (2016). Severest crisis overlooked-Worst disruption of terrestrial environments postdates the Permian-Triassic mass extinction. Nature Scientific Reports, 6, 28372.

Holtum, R. E. (1938). The ecology of tropical pteridophytes. In F. Verdoorn (Ed.), Manual of pteridology (pp. 420-450). The Hague: Nijhoff.

Hoshizaki, B. J., \& Moran, R. C. (2001). Fern growers manual. Oregon: Timber Press.

Husby, C. (2013). Biology and functional ecology of Equisetum with emphasis on the giant horsetails. The Botanical Review, 79, 147177.

Ingrouille, M., \& Eddie, E. (2006). Plants: diversity and evolution. Cambridge: University Press.

Keller, G. (2014) Deccan volcanism, the Chicxulub impact, and the endCretaceous mass extinction: Coincidence? Cause and effect. In G. Keller, \& A. C. Kerr (Eds.), Volcanism, impacts, and mass extinctions: Causes and effects (pp.57-89). Boulder, Co.: Geological Society of America, (Special Papers, 505).

Kitayama, K., Mueller-Dombois, D., \& Vitousek, P. M. (1985). Primary succession of Hawaiian montane rainforest on a chronosequence of eight lava flows. Journal of Vegetation Science, 6, 211-222.

Lindsay, S. (1995). Spore banks and conservation. Pteridologist, 2, 282284.

Lindström, S. (2016). Palynofloral patterns of terrestrial ecosystem change during the end-Triassic event - A review. Geological Magazine, 153, 223-251.

Lindström, S., \& McLoughlin, S. (2007). Synchronous palynofloristic extinction and recovery after the end-Permian event in the Prince Charles Mountains, Antarctica: implications for palynofloristic turnover across Gondwana. Review of Palaeobotany and Palynology, $145,89-122$

Looy, C. V., Twitchett, R. J., Dilcher, D. L., van Konijnenburg-van Cittert, J. H. A., \& Visscher, H. (2001). Life in the end-Permian dead zone. Proceedings of the National Academy of Sciences of the United States of America, 98, 7879-7883.

MacArthur, R. H., \& Wilson, E. O. (1967). The theory of island biogeography monographs in population biology, 1. Princeton University Press.
Magnússon, B., Magnússon, S. H., Olaffson, E., \& Sigurdsson, B. D. (2014). Plant colonization, succession and ecosystem development on Surtsey with reference to neighbouring islands. Biogeosciences, $11,5521-5537$.

McElwain, J. C., \& Punyasena, S. W. (2007). Mass extinction events and the plant fossil record. Trends in Ecology Evolution, 22, 548-557.

McElwain, J. C., Beerling, D. J., \& Woodward, F. I. (1999). Fossil plants and global warming at the Triassic-Jurassic boundary. Science, 285, 1386-1390.

McElwain, J. C., Popa, M. E., Hesselbo, S. P., Haworth, M., \& Surlyk, F. (2007). Macroecological responses of terrestrial vegetation to climatic and atmospheric change across the Triassic/Jurassic boundary in East Greenland. Paleobiology, 33, 547-573.

McLoughlin, S., Lindström, S., \& Drinnan, A. N. (1997). Gondwana floristics and sedimentary trends during the Permian-Triassic transition: new evidence from the Amery Group, northern Prince Charles Mountains, East Antarctica. Antarctic Science, 9, 281-298.

Milberg, P. (1991). Fern spores in a grassland soil. Canadian Journal of Botany, 69, 831-834.

Milberg, P., \& Anderson, L. (1994). Viable fern spores in an arable soil. Fern Gazette, 14, 299-300.

Moran, R. (2004). A natural history of ferns. Portland: Timber Press.

Nichols, D. J., \& Johnson, K. R. (2008). Plants and the K-T boundary. Cambridge: University Press.

Nichols, D. J., Jarzen, D. M., Orth, C. J., \& Oliver, P. Q. (1986). Palynological and iridium anomalies at Cretaceous-Tertiary boundary, south-central Saskatchewan. Science, 231, 714-717.

Nowak, H., Schneebeli-Hermann, E., \& Kustatscher, E. (2019). No mass extinction for land plants at the Permian-Triassic transition. Nature Communications, 10(1), 1-8.

Olsen, P. E., Fowell, S. J., \& Cornet, B. (1990). The Triassic/Jurassic boundary in continental rocks of eastern North America; a progress report. I, 247, 585-593.

Olsen, P. E., Kent, D. V., Suess, H.-D., Koeberl, C., Huber, H., Montanari, A., et al. (2002). Ascent of Dinosaurs linked to Ir anomaly at Triassic-Jurassic boundary. Science, 296, 1305-1307.

Page, C. N. (2004). Adaptive ancientness of vascular plants to exploitation of low-nutrient substrates - a neobotanical overview. In R. A. Hemsley, \& I. Poole (Eds.), The evolution of plant physiology (pp. 446-466). Amsterdam: Elsevier Academic Press.

Palmer, D. D. (2003). Hawaii's ferns and fern allies. Honolulu: Hawaii Press.

Perrie, L., \& Brownsey, P. (2007). Molecular evidence for long distance dispersal in the New Zealand pteridophyte flora. Journal of Biogeography, 34, 2028-2038.

Pillmore, C. L., Tschudy, R. H., Orth, C. J., Gilmore, J. S., \& Knight, J. D. (1984). Geologic frameworks of non-marine Cretaceous-Tertiary boundary sites, Raton Basin, New Mexico and Colorado. Science, $223,1180-1183$.

Pillmore, C. L., Nichols, D. J., \& Fleming, R. F. (1999). Field guide to the continental Cretaceous-Tertiary boundary in the Raton Basin, Colorado and New Mexico. GSA Field Guide, 1, 135-155.

Rees, P. M. (2002). Land-plant diversity and the end-Permian mass extinction. Geology, 30, 827-830.

Retallack, G. J. (1995). Permian-Triassic life crisis on land. Science, 267, $77-80$.

Retallack, G. J. (1997). Earliest Triassic origin of Isoetes and quillwort evolutionary radiation. Journal of Paleontology, 71, 500-521.

Richards, M. A., Alvarez, W., Self, S., Karlstrom, L., Renne, P. R., Manga, M., Sprain, C. J., Smit, J., Vanderkluysen, L., \& Gibson, S. A. (2015). Triggering of the largest Deccan eruptions by the Chicxulub impact. Geological Society of America Bulletin, 127, $1507-1520$.

Robinson, R. R., Sheffield, E., \& Sharpe, L. M. (2010). Problem ferns: their impact and management. In K. Mehltreter, L. F. Walker, J. M. 
Sharpe (Eds.), Fern ecology (pp. 255-322). Cambridge: University Press.

Rush, R. (1984). Raising pteridophytes from spores: the special cases. Pteridolologist, 1, 3-7.

Rydgren, K., \& Hestmark, G. (1996). The soil propagule bank in a boreal old-growth spruce forest: changes with depth and relationship to above-ground vegetation. Canadian Journal of Botany, 75, 121128.

Schneller, J. J. (1988). Spore bank, dark germination and gender determination in Athyrium and Dryopteris. Results and implications for population biology of pteridophyta. Botanica Helvetica, 98, 77-86.

Schootbrugge, B. van de, Tremolada, F., Rosenthal, Y., Bailey, T. R., FeistBurkhardt, S., Brinkhuis, H., Pross, J., Kent, D. V., \& Falkowski, P. G. (2007). End-Triassic calcification crisis and blooms of organicwalled 'disaster species'. Palaeogeography, Palaeoclimatology, Palaeoecology, 244, 126-141.

Schulte, P., Alegret, L., Arenillas, I., Arz, J. A., Barton, P. J., Bown, P. R., Bralower, T. J., Christeson, G. L., Claeys, P., Cockell, C. S., Collins, G. S., Deutsch, A., Goldin, T. J., Goto, K., Grajales-Nishimura, J. M., Grieve, R. A. F., Gulick, S. P. S., Johnson, K. R., Kiessling, W., Koeberl, C., Kring, D. A., MacLeod, K. G., Matsui, T., Melosh, J., Montanari, A., Morgan, J. V., Neal, C. R., Nichols, D. J., Norris, R. D., Pierazzo, E., Ravizza, G., Rebolledo-Vieyra, M., Reimold, W. U., Robin, E., Salge, T., Speijer, R. P., Sweet, A. R., UrrutiaFucugauchi, J., Vajda, V., Whalen, M. T., \& Willumsen, P. S. (2010). The Chicxulub asteroid impact and mass extinction at the Cretaceous-Paleogene boundary. Science, 327, 1214-1218.

Schultz, P. H., \& D'Hondt, S. (1996). Cretaceous-Tertiary (Chicxulub) impact angle and its consequences. Geology, 24, 963-967.

Simkin, T., \& Fiske, R. S. (1883). Krakatau 1883: The volcanic eruption and its effects. Washington, D.C.: Smithsonian Institution Press.

Smith, A. R. (1993). Phytogeographical principles and their use in understanding fern relationships. Journal of Biogeography, 10, 105-137.

Spicer, R. A., Burnham, R., \& Grant, P. G. (1985). Pityrogramma calomelanos, the Primary, post-eruption colonizer of Volcan Chichonal, Chiapas, Mexico. American Fern Journal, 75, 1-5.

Tanner, L. H., Lucas, S. G., \& Chapman, M. G. (2004). Assessing the record and causes of Late Triassic extinctions. Earth-Science Reviews, 65, 103-139.
Thomas, B. A. (2016). Bracken distribution on the Mount Etna lava fields in Sicily. Pteridologist, 6, 219-220.

Thomas, B. A., \& Cleal, C. J. (1998). Food of the dinosaurs. Cardiff: National Museums Galleries of Wales.

Thomas, B. A., \& Cleal, C. J. (2015). Cyclones and the formation of plant beds in late Carboniferous tropical swamps. Palaeobiodivisity and Palaeoenvironments, 95, 531-536.

Tryon, R. (1970). Development and evolution of fern floras of oceanic Islands. Biotropica, 2, 76-84.

Tryon, A. (1995). Spores of myrmecophytic ferns. Proceedings of the Royal Society of Edinburgh, 86, 105-110.

Tschudy, R. H., \& Tschudy, B. D. (1985). The "fern spike" at the Cretaceous-Tertiary Boundary, Western Interior, United States. Palynology, 9, 255-256.

Tschudy, R. H., Pillmore, C. L., Orth, C. J., Gilmore, J. S., \& Knight, J. D. (1984). Disruption of the terrestrial plant ecosystem at the Cretaceous-Tertiary boundary, Western Interior. Science, 225, 1030-1032.

Vajda, V., Raine, J. I., \& Hollis, C. J. (2001). Indication of global deforestation at the Cretaceous-Tertiary boundary by New Zealand fern spike. Science, 294, 1700-1702.

Walker, L.R. (2010) Ferns, disturbance and succession. In K. Mehltreter, R. Walker, J.M. Sharpe, (Eds.), Fern ecology (pp. 177-219). Cambridge University Press.

Whittaker, R., Bush, M. B., \& Richards, M. (1989). Plant recolonisation and vegetation succession on the Krakatau Islands, Indonesia. Ecological Monographs, 59, 59-123.

Wing, S. L. (2004). Mass extinctions in plant evolution. In P. D. Taylor (Ed.), Extinctions in the history of life (pp. 61-97). Cambridge: Cambridge University Press.

Zajączkowska, U., Kucharski, S., Nowak, Z., \& Grabowska, K. (2017). Morphometric and mechanical characteristics of Equisetum hyemale stem enhance its vibration. Planta, 245, 835-848.

Publisher's note Springer Nature remains neutral with regard to jurisdictional claims in published maps and institutional affiliations. 